嶋田甚五郎

聖マリアンナ医科大学 微生物学教室・難病治療研究センター臨床薬理部門

\title{
CLINICAL INFORMATION OFPHARMACOKINETIC ON ANTIMICROBIAL AGENTS Jingoro Shimada
}

Dept. Microbiol, Inst. Med. Sci. St. Marianna University School of Medicine

抗菌薬を例にとり、添付文書における薬物動態の在り 於つて述べる。

抗菌薬の使用目的は起炎微生物の殺隇・発育阻止であ る。したがって、その開発経緯をみると、第一に抗菌力 であり、第二が選択毒性、つまり安全性か検討され、こ れらがクリアーされると健常成人を対象に臨床第 I 相試 検が施行され、ヒトにおける薬物動態か明らかにされる。

莧物動態を検討するということは、薬の吸収、分布、 代謝、排泄( ADME) を明らかにすることであり、抗菌薬 (場合は 1) 薬と起炎微生物との相互作用を経時的に理 储することであり、同時に2) ヒトでの安全性を解析する .上でも極めて重要である。つまり、抗菌薬の有用性（有 㳇性亡安全性）を高める上で必須のデータであり、その 用法を決める上で基本となる成績である。

今、現実の添付文書に記載されている体内薬物動態を、 最も古典的な抗菌薬であるベンジルペニシリンカリウム (POG) と、最新のメロペネム (MEPM) で比較し、そ か在り方を論じてみよう。

POGの場合、「吸収・排泄 : ヒトに 40 万単位筋注時の 血中濃度のピークは 15 分後 5.73 単位 $/ m$. 以後漸减し て 3 時間後 0.25 単位 $/ m l_{0} 3$ 時間までの尿中排泄率約

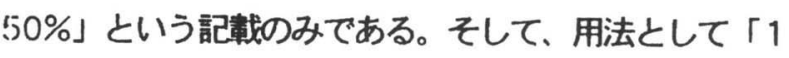
回 30 万 60 万単位 1 日 2 4 回筋注、髄膜炎、敗血症、 細菌性心内膜炎については通常用量より大量を使用（增 滅)」と記載されている。その他用法を考える上で参考に なる記載はないかと探すと「一般に高齢者では生理機能 泜下しているので減量するなど注意する」の他に薬効

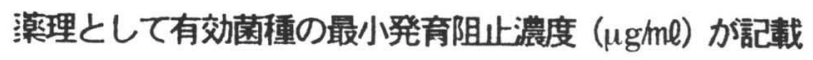
されている。これらの記載から実地医家力適正抗菌薬療 法を䒠施するのは掇めて難しい之言わざるを得ない。つ 沛り、1 日2〜 4回の決定は適応症によってなされるの
か、生理機能によってなされるのか、双方の要因を判断 する記載か不十分である。ここでいう生理機能とは、POG か腎排泄型の抗菌薬であるので、「一般に高齢者では腎機 能が低下しているので…」記載すべきであり、当然 $P \propto G$ か健常成人での腎クリアランス値も併記すべきである。 また、使用量や血中濃度が30万単位あるいは 0.25 単位 之記載され、最小発育阻止濃度は $\mu \mathrm{g} m$ 纪で表示されており、 㤢効血中濃度を維持しているのか否かか瞬時に理解でき ないのも問題である。このような古典的な抗菌薬であっ ても、欧米の記載では、「10 万単位 (0.6 g) 筋注では

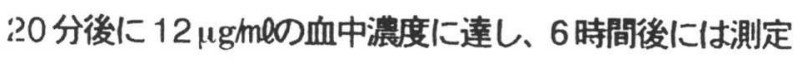
限界以下になり、尿中排泄率は6 時間までに70\%」とな つている。つまり、腎機能か正常であれば 6 時間毎に投 与すべきことは容易に理解できる。

それでは、最新のカルバペネム薬である MEPMの記載 はどこまで改良されているであろうか。「血中濃度は投与 湿に依存して推移し、半減期は約 1 時間…丁「排泄は主 上して腎より排泄され、健常成人に 30 分点滴静注後 8 時 間までの尿中排泄率葉、投与量にかかわらず、60～65\% であった」とある。つまり、MEPMは POG टほほ同様 ゆ体内薬物動態を示すことが解る。それにもかかわらず、 用法・用量は「1日0.5〜1 $\mathrm{g}$ (力価)を2〜3回に分割 し、30 分以上かけて点滴静注する。なお、年跉 · 症状に 忘じて適宜増隇するが、重症·難治性感染症には、1 日 $2 \mathrm{~g}$ (力価) まで增量することができる」と記載されてい 3。PCG と同様に血獎中半隇期短いものをなぜ 1 日 2 回の分割投与でよいのか薬物動態学の上から理解に苦し 就。

このように抗菌薬の薬物動態は開発・治験の段階から 十分理解されておらず、臨床的意義もはっきり説明され ていないのか現実である。 